\title{
Labyrinthe
}

1 | 1998

Numéro 1

\section{Cocteau et le mythe}

\section{Francis Ramirez}

\section{(apenEdition}

\section{Journals}

Electronic version

URL: http://journals.openedition.org/labyrinthe/338

DOI: $10.4000 /$ labyrinthe.338

ISSN: 1950-6031

\section{Publisher}

Hermann

Printed version

Date of publication: 15 October 1998

Number of pages: 91-92

\section{Electronic reference}

Francis Ramirez, "Cocteau et le mythe », Labyrinthe [Online], 1 | 1998, Online since 04 March 2005, connection on 01 May 2019. URL : http://journals.openedition.org/labyrinthe/338 ; DOI : 10.4000/ labyrinthe.338

This text was automatically generated on 1 May 2019.

Propriété intellectuelle 


\section{Cocteau et le mythe}

Francis Ramirez 